\title{
SDGs, Gender Equality and Women's Empowerment: What Prospects for Delivery?
}

\author{
Josephine A. Odera and Judy Mulusa
}

\begin{abstract}
Contents

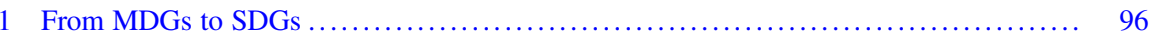

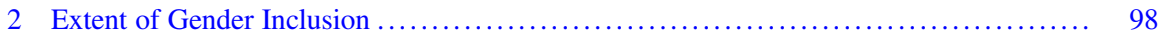

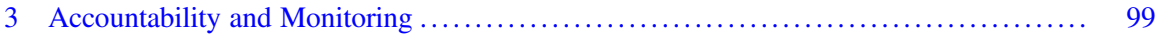

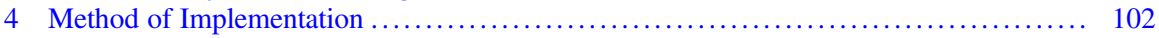

5 Macroeconomic Framework ........................................... 103

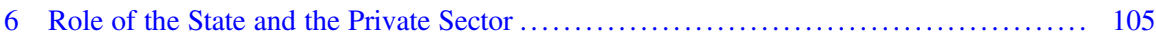

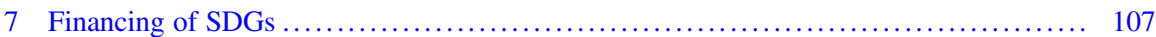

8 What Will a Transformative Approach Entail? .................................. 108

9 Conclusion $\ldots \ldots \ldots \ldots \ldots \ldots \ldots \ldots \ldots \ldots \ldots \ldots \ldots \ldots \ldots \ldots \ldots \ldots \ldots \ldots \ldots \ldots \ldots \ldots \ldots \ldots \ldots, 115$

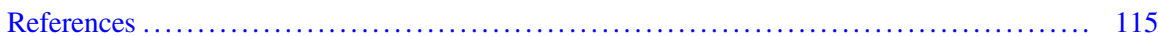

\begin{abstract}
This paper is conceptualized within the framework of gender equality and women's empowerment and proceeds from the premise that the developmental and political goal of reducing gender inequalities remains largely unmet. The 17 SDGs with goal 5 as a stand-alone on gender equality and more than half of the 17 other goals have integrated gender dimensions with measurable indicators. The pioneers for women's rights, over a century ago, focused on the labor market. Today, exclusion and discrimination in the labor market indicate that the struggle against these inequalities remains valid. Drawing on the discourse on poverty, the paper notes that this is a fundamental issue for the SDGs but that the feminization of poverty puts more women at risk. An institutional perspective to gender equality and women's empowerment beckons, if the SDGs are to deliver on this cross-cutting agenda. The paper considers the 2015 review of progress since the adoption of the Beijing Platform of Action (BPFA) undertaken at the same time as the transition from the MDGs to the SDGs and poses the question, can the SDGs deliver on gender
\end{abstract}

J. A. Odera $(\square)$

Africa Centre for Transformative and Inclusive Leadership, Nairobi, Kenya

J. Mulusa

Department of Business and Entrepreneurship, Prince Georges Community College, Largo,

MD, USA

M. Kaltenborn et al. (eds.), Sustainable Development Goals and Human Rights, Interdisciplinary Studies in Human Rights 5,

https://doi.org/10.1007/978-3-030-30469-0_6 
equality and women's empowerment. The review noted that while there has been progress at the normative level, overall progress, has been unacceptably slow, with stagnation and even regression in some contexts. Change towards gender equality has not been deep enough, nor has it been irreversible (United Nation, Res 69/313, Addis Ababa Action Agenda for the third international development conference on financing and development, 2015). The paper analyses the potential for the promise of the SDGs to make change irreversible against the background that while economic prospects appear to have risen, gender disparities have persisted and in some instances, widened, despite the common knowledge that closing the gender gap portends even greater economic growth. The paper argues for a transformative approach that can address deep structure, capacities, mindset and organizing.

\section{From MDGs to SDGs}

The 2030 Agenda for sustainable development came into effect on 1st of January 2016. It is an improvement of the previous agenda, the Millennium Development Goals (MDGs) which were supposed to have been met by 2015. The MDGs focused on poverty and its alleviation, a digression from the broader conception of development which had earlier focused on enlarging the productive capacity of economies to make possible improved living standards. It was composed of $8 \mathrm{MDGs}$ and 21 targets all focused on ending extreme poverty. They were credited for reviving the interest in development issues in areas of poverty, education and health and strengthening the willingness to put more resources into aid. However, the MDGs were criticized for applying a narrowly defined view of development with very few indicators, giving them a minimalist message, which only served to distract states from previous state commitments. The MDGs employed aggregate targets which did nothing for within country inequalities but focused resources on particular goals. ${ }^{1}$

The goals directed a western perspective of development and poverty eradication on developing countries with limited financial commitment from developed countries. They completely left out issues such as; peace, security, human rights, democracy and good governance. MDG 3 which called for promotion of gender equality and empowerment of women had one target: elimination of gender disparities in primary, secondary and tertiary education by 2015. Critics assert that this target left out all issues needed to achieve gender equality and women's empowerment including eliminating violence on women, recognizing the burden of unpaid care work that disproportionately falls on women, women's limited access to assets and resources,

\footnotetext{
${ }^{1}$ For example in health the focus was on disease specific goals (vertical programs) and this led to separate strategic plans, monitoring mechanisms, funding streams and implementation effort. The result was that there was achievement of health indicators while major deficiencies in the health systems persisted.
} 
protecting women's sexual and reproductive health rights and ending harmful traditional practices such as early and forced marriage and female genital mutilation.

The 2030 Agenda goes beyond poverty and covers a set of issues across three dimensions of development: economic, social and environmental. It is universal as it takes a holistic approach to addressing the challenges of sustainable development and it applies to all countries rather than to developing countries only. The sustainable development goals (SDGs) address key challenges such as combatting climate change and achieving gender equality not only through a stand-alone goal but in a cross-cutting manner therefore capturing the interconnectedness of development concerns. The SDGs were a result of an inclusive process with a high level of ownership from government, unlike the MDGs which were based on the millennium declaration and developed by a number of ' $U N$ insiders'. The open nature of formulating the SDGs permitted civil society organizations, UN agencies and private corporations to engage at various points in the drafting phase. The SDG universality acknowledges that progress on sustainable development 'must draw a deeper theoretical base' and the new goals embrace a form of institutional cosmopolitanism. Universal targets in the SDGs are grounded in the idea of global public goods; the environment, health and economic growth annulling the distinction between the developing and developed countries.

Compared to the MDGs, the agenda of the SDGs is broader, overall and with respect to gender and potentially more transformative. It addresses many more aspects of women's lives and therefore represents a considerable advance on the MDGs. The 2030 Agenda prioritizes gender equality as a stand-alone goal (SDG 5) and a cross cutting issue. It has its foundation in the Beijing Declaration and Platform for Action (BPFA) and the Program of Action of the International Conference on Population and Development. Up till 2015 the BPFA was the world's most powerful framework for gender equality policies and practices. It recognized the role of discriminatory laws, beliefs and practices in driving gender inequalities such as violence, early marriages and unpaid care work. The platform highlighted the need to forge a universal agenda for change and integrated social norms throughout the 12 critical areas with targets specifically addressing discriminatory institutions. ${ }^{2}$ It envisioned gender equality in all dimensions of life. A review of the BPFA in 2015 showed significant gains as governments increasingly removed discriminatory laws, girl's enrollment in secondary schools increased, women's participation in the labor market increased and birth control increased. Nevertheless, global progress has been slow, uneven and limited. A number of challenges in implementation have hindered the achievement of BPFA's vision including persistent discriminatory social norms and gender stereotypes, low levels of participation and leadership of women in decision making at all levels, chronic underinvestment in gender equality globally and absence of strong accountability mechanisms. This notwithstanding, opportunity exists to take advantage of the demographic dividend and make changes to lay the foundation of equality and sustainability.

\footnotetext{
${ }^{2}$ Such as early marriages, unequal inheritance and land rights and gender-based violence.
} 
Coming from the MDGs where the commitment to gender equality was limited to targets on gender parity in education and maternal mortality, the SDGs stand-alone goal on gender is more comprehensive and potentially a transformative commitment for women's rights. Target 5.1 to eliminate all forms of discrimination takes up Beijing's call to address discriminatory social norms, attitudes and stereotypes as well as discriminatory laws. The SDGs incorporate gender specific targets in other goals, for example: to eliminate gender disparity in education (SDG 4.5), ensure women's access to adequate sanitation (SDG 6.2), equal pay for work of equal value, (SDG 8.5), and safe and affordable transport for women (SDG 11.2). The SDGs also include 'means of implementation' as a goal (SDG 17) and as targets for each goal, admitting the need to change policies and institutions if transformative change is to take place. Inclusion of these issues indicates that the SDGs are more holistic and more aligned to gender equality than the MDG's. The most important question for the SDGs is one of effectiveness. Does the agenda and the theory of change embedded in the SDGs hold promise and are its elements transformational for women and girls? In what follows we review some of the structural elements in the SDGs that may be of current or future concern in achieving transformative changes in gender equality and women's empowerment.

\section{Extent of Gender Inclusion}

Women's empowerment and gender equality have a catalytic effect in the achievement of human development, ${ }^{3}$ however, the 2015 review of the Beijing platform still concluded that no country had fully achieved gender equality and empowerment of women and girls. Agenda 2030 confirms the centrality of women's equality and women's and girl's empowerment, several goals in the SDGs include at least some mention of gender under their associated targets. This is true of the goal on poverty (goal 1), nutrition (goal 2), education (goal 4), water and sanitation (goal 6), employment (goal 8) and cities (goal 11). Target 1.b calls on countries to '...create sound policy frameworks as the national, regional and international levels, based on pro-poor and gender sensitive development strategies...' The inclusion of this targets and other gender specific targets reflects the notion that when it comes to certain issues such as health, education, poverty and nutrition there are gender specific experiences that require attention. However, a number of the SDGs make no reference to gender; goal 7 (ensure access to affordable, reliable, sustainable and modern energy for all) makes no mention of the gender dimensions of energy when it

\footnotetext{
${ }^{3}$ Desai (2010), Onaran (2015), Nayana and Das (2017), Sinha et al. (2017) and Marone (2016). The papers look at the effect of gender equality and women's empowerment policy in wage led development strategy, land inheritance rights, child nutrition, gross development product (GDP), demographic dividend and poverty reduction.
} 
has been acknowledged that energy policy is not gender neutral ${ }^{4}$; goal 9 (build resilient infrastructure and promote inclusive and sustainable industrialization) does not take account of the fact that poor infrastructure exacerbates the gender gap and makes no mention of the need to adopt gender sensitive indicators ${ }^{5}$ to build a base for successful gender approaches in infrastructure; goal 12 (ensure sustainable consumption and production patterns) is silent on gender; the adaptation target in goal 13 (climate change) is not linked to gender, yet gender disparities increase vulnerability of women and girls to climatic risk and adaptation initiatives that do not take gender into account may unintentionally replicate gender inequality ${ }^{6}$; and goal $16^{7}$ (peace and inclusive societies) lacks gender specific language. To effectively work towards achievement of gender equality and women's empowerment gender must be integrated across all SDGs and gender considerations must be included in all sustainable development work.

\section{Accountability and Monitoring}

Global initiatives designed to benefit the daily lives of people risk not being implemented appropriately if at all, unless they are monitored and accountable. The selection of appropriate results and indicators is essential to strengthen accountability for implementation of the SDGs and particularly to ensure gender equality and women's empowerment. Gender indicators were first developed during the Fourth World Conference on Women in Beijing in 1995. Since then attempts to transpose broad questions and aspirations into gender indicators remains a daunting task. There is an emphasis on quantitative targets at the expense of context, history and culture-for instance there is no other measure of poverty other than the money metric (USD 1.25 per day) which fails to capture many of the hardships that constitute poverty, for example child labor, unpaid women labor, undernourishment, illiteracy, exposure to violence and lack of access to water, shelter and sanitation, factors that affect women disproportionately. The same argument may be applied to the measure of unpaid care work. In 1995 the Beijing platform highlighted the

\footnotetext{
${ }^{4}$ Gender dimensions in energy can be captured by examining links between energy policies and women's welfare, productivity and empowerment, see Sharma et al. (2016), Half et al. (2014) and O'Dell et al. (2014).

${ }^{5}$ Such as: estimate of time savings per trip for women, improved frequency of trips to health clinics and change in cooking practices.

${ }^{6}$ Climate change adaptation is inherently context specific and often based on changing behavior implying that effective gender responsive adaptation responds to unique gender dynamics of the target area, Wolf (2011).

${ }^{7}$ Explanations put forward to account for the exclusion of gender in this goal include; the relatively strong governance orientation of gender equality in SDG 5, political tension surrounding SDG 16 prior to its adoption and compression of the goal necessitated by the merging of what had originally been two separate goals, see Goetz and Jenkins (2016a).
} 
importance of tackling the unequal distribution of paid and unpaid care work. Focus on unpaid care work within the framework of the SDGs echoes Beijing's call.

Razavi notes that the wording, 'recognize and value unpaid care work' draws attention to counting unpaid work in statistical terms, which has its value in terms of bringing the issue of unpaid care work to the limelight, but the action on this target should go a couple of steps further to promote shared responsibilities between men and women. ${ }^{8}$ Chopra notes that "economic empowerment is not just about women's participation in the labor market but participation in a way which takes into account their unpaid work responsibilities which is decent, well paid and which means flexible working hours and a choice of locations." 9

Secondly, a number of indicators do not appear to capture the full intention of the targets in the SDGs whereas there are some targets that do not capture the full intention of the goal. Goal 5 has six targets; one of them, target 5.2, is to 'eliminate all forms of violence against all women and girls in the public and private spheres, including trafficking and sexual and other types of exploitations'. This target is measured by two indicators 5.2.1 '... proportion of ever partnered women and girls aged 15 years and older subjected to physical, sexual or psychological violence by a current or former intimate partner in the last 12 months by form of violence and age group' and 5.2.2 '...proportion of women and girls aged 15 years and older subjected to sexual violence by persons other than an intimate partner in the last 12 months, by age group and place of occurrence'. The broad goal has been subdivided into a more limited target and the indicators used, measure only a small part of the issues in the target. The two indicators measure frequency with reference to age, type of violence and type of relationship. Issues such as trafficking and other forms of exploitation are not captured by the indicators. These indicators make no mention of the experience of violence, the trajectory of the relationships, the cultural meanings of gender, marriages and sexuality as well as the social context of the violence amongst other factors. ${ }^{10}$

Establishing the transformative nature of the SDGs begs the question are the targets specific, measurable, attainable and time bound? Pogge and Sengupta note that in some instances the SDGs are not specific enough and in instances where the SDGs include specific means of implementation they fail to specify who is responsible for each goal and or target. ${ }^{11}$ They mention that the target on education parity which is an improvement over the MDGs ${ }^{12}$ is lacking in terms of specific crucial indicators pertinent for girls: distance to school; safety of schools; travel to school;

\footnotetext{
${ }^{8}$ Razavi (2016). Measuring promotion of shared responsibilities within households and family creates another challenge.

${ }^{9}$ Chopra (2015).

${ }^{10}$ Merry (2016).

${ }^{11}$ Pogge and Sengupta (2015).

${ }^{12}$ It has shifted focus from enrollment in primary schools to include secondary education and early childhood learning while expanding the focus from enrollment to completion.
} 
early marriages and pregnancies ${ }^{13}$; target 5.5-on representation of women at national or local government level lacks an aspirational percentage and metrics to measure women's levels of influence in power and this is the same concern raised about the targets under the energy goal (goal 7). Target 5.1-end all forms of discrimination against all women and girls everywhere, fails to specify the efforts required to achieve this and it also fails to hold a particular agent accountable while target 2.1 - end hunger and ensure access by all people in particular the poor people in vulnerable situations, fails to assign effort to specific actors/agents. Koehler criticizes the long time frame associated with some of the targets/indicators ${ }^{14}$; for instance the accomplishment of the targets on education parity and reduction in maternal mortality were pushed to the year 2030 while the global maternal mortality target's ratios-less than 70 per 100,000 live births, are less ambitious than the targets that high income countries have set for themselves-16 per 100,000 live births. ${ }^{15}$

To emphasize the problem of gender indicators and or targets it is worth noting that during the drafting phase of Agenda 2030, there was a proposal by gender equality lobbyists to include a target on stronger women's rights organizations in the SDG framework. ${ }^{16}$ This target did not make it into the final SDG framework because of the complexity of measuring the size and strength of women's movements, a number of measures that have been proposed in literature have proved to be inadequate. ${ }^{17}$ Over and above this, out of the 230 unique global SDG indicators 53 explicitly reference women, girls, gender or sex, including the 14 under SDG 5 however, UN Women finds that there are no internationally established methodologies or standards for 23 out of the 53 gender related indicators.

Lastly lack of data further compounds the inadequacies of the gender indicators, it makes it harder to accurately identify, analyze and monitor the separate needs and vulnerabilities of women, girls, men and boys and develop effective evidence-based policies and solutions. A study by Data $2 \mathrm{x},{ }^{18}$ has reviewed the availability of sex disaggregated data and found that while $80 \%$ of countries regularly produce sex disaggregated data statistics on mortality, labor force participation and education and training, less than one third of countries disaggregate statistics on informal

\footnotetext{
${ }^{13}$ Early marriages and pregnancies were listed by the BPFA as major causes of girls lower educational performance and higher dropout rates causing the gap in school completion rates for girls.

${ }^{14}$ Koehler (2016).

${ }^{15}$ United Nations (2015), p. 38.

${ }^{16}$ Goetz and Jenkins (2016b).

${ }^{17}$ For example: number of women active in women's organizations or number of women's organizations in a country, capacity of civil society actors to accumulate political and social resources to support gender equality and proportion of managers of civil society organizations and media professionals that are women Htun and Weldon (2012), Mazur et al. (2012) and UN Women (2013).

${ }^{18} \mathrm{An}$ initiative started by Hilary Clinton to improve the quality of gender data and its analysis to drive better policy making http://www.data2x.org/.
} 
employment, entrepreneurship, violence against women and unpaid work. ${ }^{19}$ Lack of disaggregated data masks the differences among various groups making it challenging to identify the needs of marginalized populations and it results in a review mechanism that is based entirely on the interpretation of government officials. Given the weak and undemocratic nature of many global economic or political governance bodies this becomes a big challenge for implementation of the SDGs in general. Investment in data offers a critical impetus to revive Beijing's commitment to address key data gaps by strengthening national capacities.

\section{Method of Implementation}

One of the limitations in implementing the MDGs stemmed from the lack of an 'opaque system' to monitor and report progress. There were no institutional mechanisms through which beneficiaries could engage in shaping or challenging decisions at the domestic level in a meaningful way. ${ }^{20}$ Situating SDGs in international law and politics by considering their legalization, is important in determining the successful implementation of the SDGs. Legalization, a particular form of institutionalization shows the degree to which imposition of international legal constraints on governments can be applied. It refers to a set of characteristics defined as a continuum based on three dimensions; obligation, precision and delegation. ${ }^{21}$ Scholars like Kenneth Abbot and Duncan Snidal distinguished harder from softer international law ${ }^{22}$ based on the three dimensions; obligations- harder law will have a higher degree of legalization and softer law will have weak or no legal obligations; precision -institutions may be written in more or less detailed and precise language with harder law having a high degree while softer law comprises vague, general or abstract wording and; delegation-in harder law interpretation or enforcement is left to independent third parties ${ }^{23}$ while with softer law interpretation and enforcement is kept within parties allowing for political maneuvering.

SDGs are seen to be at the soft end of the continuum; there are no hard obligations, legal rules and commitments that impose a particular type of binding obligation $^{24}$; precision which narrows the scope of interpretation is present in some targets $^{25}$ but is generally low as most targets do not unambiguously define certain

\footnotetext{
${ }^{19}$ Buvinic et al. (2014).

${ }^{20}$ Nayyar (2012) and McArthur (2013).

${ }^{21}$ Abbott et al. (2000), Karlsson-Vinkhuyzen and Vihma (2009) and Goldstein et al. (2000).

${ }^{22}$ Hard legalization is where all three properties are maximized or are 'high' and soft legalization involves different combinations of the 3 attributes.

${ }^{23}$ Like an international tribunals, courts and arbitrators.

${ }^{24}$ Breach of legal obligations creates a 'legal responsibility' which is lacking in SDGs.

${ }^{25}$ See target 3.4 'reduce by one third premature mortality from non-communicable diseases'.
} 
conduct but rather they state vague and aspirational outcomes ${ }^{26}$; delegation of authority to designated third parties to implement agreements, is lacking as the SDG framework appears to embrace political bargaining between parties who may accept or reject proposals. The fact that SDGs are a statement of aspirations: a voluntary agreement rather than a binding treaty presents an opportunity for states to adopt a more ambitious agenda but creates a drawback in so far as states may be more tempted to skirt their commitments. It is noted that the commitments and precision in SDGs fall short of those made in the Beijing Platform. The SDGs aim broadly for equal access to justice while the BPFA specifically commits governments to ensuring access to free or low cost equal services designed to reach women living in poverty; secondly, SDGs call for promotion of peaceful and inclusive society while BPFA called for reduction in excessive military expenditure and controlling availability of arms. Moreover, target 5.4 'recognize and value unpaid care work. . . as nationally appropriate', target 5.1 'end all forms of discrimination' and target 5.5 'ensure women's full and effective participation' are open to many interpretations since there are no clear definitions of unpaid care work, discrimination and effective participation. On a more general note lack of precision is observed under the goal on ending poverty, there is no commitment to a collectively maintained universal social protection floor, but merely the call for "nationally appropriate social protection systems and measures'. In conclusion the soft nature of the SDG laws is emphasized by the language in the resolution adopting the 169 targets-'[they] are defined as aspirational and global with each government setting its own national targets guided by the global level of ambition but taking into account national circumstances... ${ }^{27}$. This wording begs the question which targets will be considered more important when countries develop their own targets?

\section{Macroeconomic Framework}

The type of economic thinking dominating current global macroeconomic policy has been described as neoliberalism. It places competition at the center of human relations and sees a diminished role of government. It is characterized by austerity measures, global integration and increased production. Feminists highlight that these policies are gender neutral. They do not take into account economic and social rights, distributive outcomes or gender equality. Indeed, they typically focus on a narrow set of goals, such as raising economic growth rates or reducing inflation to extremely low levels. These measures are not necessarily linked to more fundamental objectives such as human development, well-being and the enjoyment of rights. Feminist economists have demonstrated a number of points which cast doubt on the assumed link between gender equality and economic growth. For example, with

\footnotetext{
${ }^{26}$ Only 29\% of targets in SDGs are well defined (Hazelton 2015).

${ }^{27}$ Agenda 2030 paragraph 55.
} 
financial globalization the costs of austerity measures, privatization of government assets and services, cuts in public expenditure, welfare policies and social protection have historically been and continue to be borne by women as women's unpaid care work acts as a stabilizer of economic financial crisis. ${ }^{28}$ Women are effectively assuming the costs of current failure to regulate markets in the form of unemployment, low wages, and job insecurity. Unregulated global financial speculation has also led to the rise in prices that destabilize household budgets, and impact women as caregivers and as small farmers. BPFA openly challenged austerity programs and the impact of these macroeconomic policies on women. The Platform acknowledged that the neo liberal "trade not aid"-model of development was and is failing the majority of the world's women.

Agenda 2030 contains a number of targets that aim at guarding against global inequality and problems of future financial crises: goal 17 has a target to enhance macroeconomic stability and another to respect each country's policy space; target 10.6 makes mention of enhanced representation; goal 8 promotes economic growth with a hope for increased productivity, technological change and resource efficiency; goal 12 mentions sustainable production and consumption patterns; and goal 10 emphasizes reduction of inequality within countries, that is, attain growth for the bottom $40 \%$ of the population at a rate that is higher than the national average. However, Ponte and Enriquez assert that Agenda 2030 does not explicitly recognize the link between women's human rights, gender equality and the global economic governance policies. ${ }^{29}$ Analyzing the aforementioned SDGs shows why this is the case. Goal 10, on inequality relies on the old model of industrial growth; with emphasis on increasing levels of extraction, production and consumption. It calls for at least a 7\% annual GDP growth in least developed countries and higher levels of economic productivity across the board. Target 10.11 concentrates on the bottom $40 \%$ of the population making it a pro poor growth model. The target wants to reduce poverty by 'ratcheting' the poor up while leaving the wealth and power of the top $1 \%$ intact. The target makes no mention of the link between poverty and exploitation and monopolization of resources by the few wealthy countries. This inequality goal does not ask for a specific level of growth in incomes of the poorest but simply any growth at all above the national average. Goal 8 is devoted to economic growth, specifically export oriented growth, in keeping with neoliberal models. The emphasis on the economic growth approach fails to respond to macroeconomic and structural drivers as well as environmental limitations of growth. Increasing incomes does not automatically translate into gender equality or better well-being for females ${ }^{30}$ relying solely on growth is no panacea. Whether growth contributes to gender equality depends on growth patterns, that is, which sectors drive economic growth and if they are capable of generating decent employment for women. It also depends on the role of the state in redistributing growth and the

\footnotetext{
${ }^{28}$ Ponte and Enriquez (2016) and Antonopoulous (2014).

${ }^{29}$ Ponte and Enriquez (2016).

${ }^{30}$ See Razavi (1997).
} 
presence of structures that curtail women's ability to take advantage of the growth. Relying on economic growth is a supply side story, it is based on the premise that individual countries are ultimately responsible for their development provided their policy space is respected (target 17.15). Goal 17.10 calls for more trade liberalization but is silent on the unfair trade regime of the World Trade Organization (WTO) and the many bilateral trade and investment agreements. ${ }^{31}$ In many countries, trade liberalization has led to a reduction in government revenues, with implications for policies to support gender equality. Trade liberalization increases gender inequality in the labor market ${ }^{32}$ as women's low wages render them the workforce of choice for the export market. Emphasis on export markets leads policy makers and producers to see wages as a cost rather than a source of potential demand, leading to strategies to reduce wages. Trade agreements between countries also often have provisions that limit the policies that individual governments can adopt, such as measures that aim to promote and support domestic productive activities and investment. Such agreements frequently have different consequences for women's and men's employment. Looking back at the effects of the policies in the 1980s and the 1990s by the World Bank and the International Monetary Fund (IMF) makes this more evident, as the increase in exports depressed prices and led to deterioration in the terms of trade. Recent trade agreements like the Trans Pacific Partnership (TPP) grant stronger corporate control of the world's resources and trade flows. This presents enormous risks for realization of human rights, ecological social and gender justice. Lastly the SDGs are silent on financial speculation and the need for greater regulation of financial markets. Goal 17.13 talks of the need to 'enhance global macroeconomic stability' through policy coordination but gives no specific targets while no mention is made of tax evasion and avoidance which drains developing countries.

\section{Role of the State and the Private Sector}

SDGs explicitly call for involvement of a wide range of actors including the private sector. Progress on many of the 17 goals will depend on private sector contributions ${ }^{33}$-goal 12 on responsible consumption and production urges Transnational Corporations (TNCs) to adopt sustainable practices and integrate sustainability information while goal 17 emphasizes partnerships. The Addis Ababa Action Agenda (AAAA), the outcome document for finance and development, underlines the importance of the TNC's in achieving SDGs. Needless to say, the overall impact

\footnotetext{
${ }^{31}$ Hickel (2015).

${ }^{32}$ See Farha et al. (2017); United Nations Inter-Agency Network on Women and Gender Equality.

${ }^{33} \mathrm{TNCs}$ account for as much as $25 \%$ of global GDP (Patchell and Hayter 2013), the private sector accounts for $90 \%$ of jobs in less developed countries, foreign direct investment is outpacing development assistance 4 to 1 .
} 
of TNCs is multifaceted and complex and varies depending on a number of factors. ${ }^{34}$ Cees Van Beers states that competition from TNCs creates a pervasive incentive structure that encourages states to go easy on regulations as well as economic and civil rights in the interest of fostering a suitable business environment and compliant labor force. ${ }^{35}$ From this perspective discrimination against women is imperative and is a stepping stone towards more competitive status. Tied to the problem of TNCs is the issue of International Financial Flows (IFFs). IFFs also have a disproportionate gender impact, draining critical resources that could otherwise be allocated to advancement of women's human rights. IFFs from Africa result in estimated losses of over $\$ 500$ billion per year with $65 \%$ due to commercial tax evasion and tax avoidance including transfer of income to tax havens. Unlike the SDGs the BPFA takes a stand on the IFFs stating that the government should analyze and adjust macroeconomic policies including taxation and external debt policy from a gender perspective to promote a more equitable distribution of productive assets. Current legal and political frameworks in many developing countries allow TNCs to benefit from tax evasion. Be that as it may, the 2030 Agenda lacks an internationally binding instrument to regulate activities of TNCs in international human rights law particularly in the global south. Relying on the TNCs may circumvent one of the SDG's central goals.

The SDGs do not clearly acknowledge the role of the states in delivering SDGs particularly in human rights and gender equality. Goal 17.16 which reads '... enhance the global partnership for sustainable development, complemented by multi-stakeholder partnerships...' may imply that states have a primary role, but the document does not state this explicitly. 'Partnerships' implies an increased role for the private sector a factor which is questionable based on the principles of equality. Public private partnerships (PPPs) have been promoted at the national level and by the United Nations development system as the best way to advance investments in areas of special relevance for women and human rights particularly in social infrastructure and social services. The perspective that PPPs can narrow the gender gap is questionable. Critics have argued that PPP projects do not deliver outcomes and the problems are heightened in countries with weaker monitoring and regulation mechanisms by the state. ${ }^{36}$ Though the influence of PPPs emphasizes efficiency and effectiveness, the profit motives of the private sector threatens realization of human rights and would worsen gender equality. PPPs have changed how interventions are designed and managed, focusing more on showing value for money through quantifiable indicators. This is evident in health care, where existing PPPs do not contribute to alleviating fiscal pressure but rather exacerbate the fiscal

\footnotetext{
${ }^{34}$ Including local capacity of production and innovation, host government policies, investor motives the investment model and firm characteristics.

${ }^{35}$ Van Beers (2000).

${ }^{36}$ See Romero (2015).
} 
unsustainability and often fail to deliver services needed by women especially those living in poverty. ${ }^{37}$

In tandem with the role of the private sector vis a vis the state, is the political will. A number of factors raise concern over the extent of the political will. During the preparation phase of the SDGs countries from Africa and Arab groups contested references to long agreed commitments on women's rights like the BPFA and the international conference on population and development. A record 143 countries guaranteed equality between men and women in their constitutions by 2014 but another 52 have not yet taken this step (UN Women, ESAR). With regard to specific gender targets in the SDGs it is noted that some countries strongly opposed the inclusion of sexual and reproductive health rights in the SDG framework, to the extent that the issue of sexual rights is still missing in the SDGs. Weak political commitment at the preparation phase of the SDGs was also observed when a number of governments rejected proposals for stronger financial regulation that would tap the wealth of the top $1 \%$ and curb illicit flow of finances from developing countries ${ }^{38}$ and when countries in the global North refused to accept the creation of an intergovernmental tax UN body on tax matters.

\section{Financing of SDGs}

The review of the BPFA after 20 years showed that underinvestment in gender equality and women empowerment contributed to slow and uneven progress in all the 12 critical areas of concern. An overview of donor support shows low levels of financing-in 2012-2013, USD 4 billion targeted gender equality as a principal objective, representing 5\% of all OECD-DAC aid, while women's economic empowerment received $2 \%$ of aid. By comparison, USD 22 billion or $25 \%$ targeted gender equality as a secondary objective. This adds up to only $30 \%$ of aid being responsive to women's needs and interests. Interestingly though, aid to gender equality has grown at a faster rate than aid overall. While total aid grew at a rate of $1 \%$ annually aid to gender equality grew by $4 \%$ annually. This figure was even higher in fragile states with an annual growth rate of $10 \%{ }^{39}$ Despite this trend, investments in gender equality are vastly insufficient as the 2030 agenda is estimated to cost between USD 2-3 trillion every year for 15 years, this represents $4 \%$ of world's GDP yet developed countries have committed to provide only $0.7 \%$ of GDP in aid.

\footnotetext{
${ }^{37}$ See Gideon and Porter (2014).

${ }^{38}$ The final draft of the SDGs acknowledges the need for international financial institutions (IFIs) to continue to respect the policy space of each country consistent with IFIs organizational mandates which are very much set by the developed countries anyway. By adding this the SDGs missed an opportunity to transform the international financial institutions.

${ }^{39}$ OECD 2015 States of Fragility 2015: Meeting post 2015 Ambitions, OECD, Paris.
} 
Aid in support of gender equality is concentrated in social sectors of health and education with significant underinvestment in gender equality in economic and productive sectors. In 2013 only $2 \%$ (ibid) of aid to the economic and productive sectors targeted gender equality as a principal objective. The transport and energy sectors receive the bulk of bilateral aid to climate change but only a very small proportion of this targets gender equality. In 2014 climate ODA that also supports the achievement of gender equality was USD 8 billion, accounting for $31 \%$ of bilateral ODA. ${ }^{40}$ Only $3 \%$ of this, had gender equality as a principal objective. Ensuring climate financing instruments are responsive to women's needs and priorities remains a major concern in the SDGs. Currently only 20-24\% of jobs in renewable energy sector are held by women, yet projections show that green jobs could lead to millions of new employment opportunities in the next few years. An analysis of the Nationally Determined Contributions (NDC) submitted by parties to the United Nations Framework Convention on Climate Change (UNFCC) shows that only $40 \%$ included any reference to gender and women.

The gap between policy commitments and financial commitments is also pronounced in the area of peace and security and sexual and reproductive health. In 2012-2013 only $2 \%$ of aid to peace and security in fragile states targeted gender equality as a principal objective. The same applies to aid to ending violence against women and girls. Funding for women's civil society organizations and institutions constitutes a very small percentage of total aid to gender equality. In fragile states women's equality organizations and institutions received just $1 \%$ of total aid targeting gender equality, ${ }^{41}$ yet women's organizations are at the forefront of peacebuilding and state building efforts.

\section{What Will a Transformative Approach Entail?}

Hillenbrand et al. define a gender transformative approach as one that aims to move beyond individual self-improvement among women toward transforming the power dynamics and structures that serve to reinforce gendered equities. ${ }^{42}$ Such an approach goes beyond the 'symptoms' of gender inequality to address the 'social norms, attitudes, behaviors and social systems that underlie them'. Rottach et al. ascribe gender transformative change to a set of issues including; promotion of the position of women, challenging resource distribution and allocation of duties between men and women and addressing the power relationships between men

\footnotetext{
${ }^{40}$ OECD 2015 Making climate finance work for women: Overview of bilateral ODA to gender and climate change, OECD Paris.

${ }^{41}$ OECD Aid in support of gender equality and women's empowerment. http://www.oecd.org/dac/ stats/gender-related-aid-data.htm Accessed on 10/27/2017.

${ }^{42}$ Heillenbrand et al. (2015).
} 
and women in the community. ${ }^{43}$ The Interagency Gender Working Group notes that gender transformative approaches 'actively strive to examine, question and change rigid gender norms and imbalance of power'. ${ }^{44}$ These definitions confirm Beijing's message that social norms play a critical role in accelerating progress toward gender equality. The challenge of transformative strategies is targeting the structural foundations of gender inequality and ensuring participation while, recognizing the diversity of girls and women's experiences to ensure the most marginalized are included in decision making even in the political process. Based on lessons learned to be transformative action is required in the five priority areas discussed below.

\section{Strengthening Accountability Mechanisms}

Establishment of a rigorous follow up and review mechanism that is transparent, state led, incorporates peer review and allows for participation by the civil society is key. Linking the SDGs and their targets to the Convention on Elimination of Discrimination Against Women (CEDAW) and the implementation of the BDPFA enables a feminist accountability framework where member states must report their progress and can be challenged by civil society. The Commission on the Status of Women (CSW) also has a critical role to oversee implementation of the 2030 Agenda.

Secondly accountability banks on clear indicators which will require complimenting the international targets/indicators with contextually relevant benchmarks in individual states. Gender sensitive indicators must be contextualized to multiple dimensions of disempowerment encountered by the female population. They should be ambitious and not resort to what is easy to measure and reflect need rather than availability of data. To come up with a list of indicators that is narrow enough to be usable, applicable and achievable for every country while remaining separate from any political influences requires balancing a wide range of competing priorities and technical limitations. Use of sex disaggregated indicators will allow tracking of the degree to which women have benefitted (or not) from whatever progress is made. A number of global accountability mechanisms and initiatives have been established to drive progress on data and accountability when it comes to issues affecting women. ${ }^{45}$ Use of creative and progressive indicators to make targets more specific and incorporate a rights-based approach into the language of the indicators/targets is imperative.

\footnotetext{
${ }^{43}$ Rottach et al. (2009).

${ }^{44}$ Interagency Gender Working Group in Heillenbrand et al. (2015).

${ }^{45}$ These include the High Level Political Forum, Universal Periodic Review, The Independent Accountability Panel, Equal Measures 2030, Data 2X, Making Every Woman and Girl Count, Countdown to 2030 and the UN System Wide action Plan of Gender Equality.
} 
Securing national ownership of gender related SDGs and targets in the early stages of implementation is an impetus to accountability. Governments voluntarily adopted the SDGs and they bear their overall responsibility. Localization-the process of defining, implementing and monitoring strategies at the local level for achieving global, national and subnational SDG targets is crucial. Coupled with deep legal and legislative changes to protect women's rights, governments should ensure that the capacity of national statistical organizations become more transparent, inclusive and capable of mainstreaming gender accountability and producing disaggregated data to guide interventions and hold governments accountable. Ownership of the SDGs calls for multi-channeled awareness raising campaigns at the national and local level, establishing and sustaining substantive dialogues among multiple stake holder bodies and supporting efforts of women machineries and CSOs to play leadership roles in the implementation of Agenda 2030.

\section{Use of Soft Law to Establish a Consensus}

Although soft law has not been acknowledged as law due to the lack of binding character, it has significant and extensive effects on establishment and development of international law. Soft law presents a flexible environment for consensus free from parliamentary approval or long years of application as is the case with customary law. ${ }^{46}$ Increased compliance with soft law will require more specific rather than vague agreements, focus on regulating state actors rather than non-state actors, forming links with hard law, norms on absenteeism rather than those requiring actions and use of financial incentives. ${ }^{47}$

\section{Transforming the Economy to Achieve Gender Equality}

As part of the commitment to gender equality, macroeconomic policymaking should incorporate distributive impact analyses that allows for macroeconomic policies to be evaluated in terms of their effects on women and men. Specifically, there is a need to analyze the effects of public spending, tax policy and monetary policy on gender equality and where gender inequalities are uncovered, governments must take steps to correct them. Other policy areas with macro-level impacts, such as the negotiation of trade agreements, also need to be subjected to greater scrutiny. Trade policy must have a good understanding of where women are in the economy while the trade negotiators must be provided with information on sensitive sectors where trade liberalization should be expedited, delayed or exempted with a view to enhancing

\footnotetext{
${ }^{46}$ Kaltenborn and Kuhn (2017).

${ }^{47}$ Shelton (1997).
} 
or protecting female employment or female owned enterprises. Less developed countries have traditionally been more cautious about including non-trade concerns in the trade agreements, they fear that these considerations may become a financial burden or may result in trade barriers. For these countries a transformative approach will require a paradigm shift to ensure gender equality needs are included in the core text of trade agreements, to increase political commitment. A number of examples are seen in current trade agreements: the Cotonou Agreement ${ }^{48}$ states that '...countries should respect international conventions regarding women's rights and gender equality...'; the North American Agreement on Labor Cooperation, a side accord that accompanies the North American Free Trade Area (NAFTA) reads '... promote cooperative activities regarding among others (a) equality of women and men in the work place... ${ }^{49}$ and the US-Central America Free Trade Area embedded gender considerations within their capacity development mechanismsthe Labor Cooperation and Capacity Building mechanisms which sets out gender equality as a cooperation and capacity building priority. ${ }^{50}$ Addressing trade imbalances is now even more urgent given the gigantic trade agreements being hatched across the world's largest economies. These agreements grant stronger corporate control over the world's resources and trade flows and this presents an enormous risk for the realization of human rights, ecological, social and gender justice.

To support global sustainable development, macroeconomic policies will have to target more closely real variables, such as the level of output and employment. Indeed, this may require shifting emphasis from intermediate targets such as low inflation, external balance, and low fiscal deficits. But moving away from intermediary goals does not mean that macroeconomic stability should be abandoned. On the contrary, a primary goal of policy is to ensure stable financial and monetary conditions in support of productive development. Thus, a critical task of macroeconomic policies, necessitates the reorientation of economic dynamics towards equality-oriented production, consumption and reproduction patterns with attention to transformative redistribution of resources. This requires extensive regulation of financial markets, market structures and competition and on redistributing mechanisms and labor markets. Macroeconomic policies to support sustainable development must give greater weight to domestic demand, policies that can be pursued by all countries simultaneously, without counter-productive wage and tax competition. In addition, central banks can use their regulatory power to channel credit to uses that support the realization of rights and promote gender equality. Policies and regulations can also encourage credit to be extended to improve housing, stimulate job-creating investments or promote access to loans for self-employed workers in informal activities, many of whom are women. Greater emphasis should be placed on developing redistributive economic policies and social policies that incentivize an

\footnotetext{
${ }^{48}$ http://ec.europa.eu/development/icenter/repository/agr01_en.pdf.

${ }^{49}$ http://www.dol.gov/ilab/regs/naalc/naalc.htm.

${ }^{50}$ www.ustr.gov/sites/default/files/uploads/agreements/cafta/asset_upload_file320_3936.pdf.
} 
equitable distribution of household labor for example those that increase government revenue and accountability rather than cutting important basic services. ${ }^{51}$

Public investment spending in social infrastructure ${ }^{52}$ would generate public employment in labor intensive social services and could increase female labor force participation rate via socializing the invisible and unpaid care work. An analysis done by feminist economist at the UK Women's Budget Group ${ }^{53}$ shows that investing $2 \%$ of GDP in the care industry would increase women's employment rates between 3.3 and $8.2 \%$. In the US according to this analysis, such an investment would create nearly 13 million new jobs, much more than investing $2 \%$ of GDP in construction sector, which would create around 7.5 million jobs. Some $67 \%$ of the new jobs created by investment in the care sector would go to women, compared to $35 \%$ of the new jobs from investment in the construction sector. These jobs need to be made more attractive for all, by improving pay and working conditions in these industries. A reorientation toward high skilled decent service sector jobs should be promoted instead of reliance on low pay service jobs with weaker labor unions. However, as much as public investment will reduce the amount of unpaid care work there is need to redistribute the remaining work equally between men and women. This requires action from governments, businesses, trade unions and women's organization to mobilize resources and change cultures.

\section{Increasing Investments in Gender Equality}

There is need for transformative financing that increases investment and resources to meet new commitments. Funding of women's rights organizations is critical and will require earmarking of resources. The Addis Ababa Action Plan ${ }^{54}$ outlines transformative policy and financing actions to accelerate implementation of existing commitments in the Beijing Declaration and Platform of Action and to meet new commitments on gender equality and women's empowerment. It emphasizes the importance of progressive budgeting and or gender responsive budgeting and tax policies which have enormous scope to reduce gender inequalities. Removing gender biases in taxation systems could help level the playing field. Mobilizing domestic financial resources through increased domestic borrowing has been a trend in emerging market economies. Within the context of a prudent medium-term fiscal framework and a public debt management strategy this may be a useful source of

\footnotetext{
${ }^{51}$ Floro and Willoughby (2016).

${ }^{52}$ Including child care, education and elder care as well as water and electricity.

${ }^{53}$ Analysis done by feminist economists at the UK Women's Budget Group.

${ }^{54}$ Please see "Policy Hub - Transformative financing and goals for gender equality and women's and girls' empowerment - Addis Ababa and New York 2015”, European Parliament, Directorate General for Internal Policies, Policy Department C: Citizens' Rights and Constitutional Affairs, Women's Rights \& Gender Equality, July 2015. http://www.europarl.europa.eu/RegData/etudes/ IDAN/2015/519237/IPOL_IDA(2015)519237_EN.pdf.
} 
additional revenue. Such borrowing has a catalytic impact on domestic financial sector development but for developing countries accumulation of debt and the risk of experiencing debt distress is a concern.

OECD admits that for every US dollar which comes to developing countries as ODA three US dollars leave these countries as illicit financial flows. Hence reducing outflow due to illicit financial flows, debt service repayments and maintenance of foreign reserves in developed countries will mobilize domestic resources for southern countries. SDG 17, the global partnership goal, creates space for individual countries but shields the world's most powerful agents; the rich countries, international organizations and trans-national corporations (TNCs) from any concrete responsibilities in achieving the SDGs. Given their wealth and resources, they should take the lead in providing resources and implementing systematic institutional reform to address the root cause of poverty. These reforms would include changing the rules that encourage illicit financial outflows from developing countries or force poor countries to pay debt with interest on loans accumulated by illegitimate and unaccountable rulers. If the SDGs hold these affluent agencies accountable for their role in making the sustainable development work, then the concept of partnership and universalism in the SDGs would be more meaningful. National Assessment Plans (NAPs) should be designed to encompass SDGs while respecting human rights. For TNCs this means adopting a positive approach toward equal payment whilst ensuring TNC's activities are non-exploitative. Aligning corporate and SDG indicators is imperative. SDGs indicators should be set so that companies can set sustainability commitments related to their core business and report against them in line with the SDGs. Several TNCs already report against targets covered by SDGs such as environmental impact and women's empowerment. The NAPs should have remedy schemes for those affected by human rights violations.

\section{Engendering Climate Change with a View to Attaining Gender Equality and Sustainable Development}

It is important to remember that women are not only vulnerable to climate change, but they are effective actors or agents of change. This is recognized in the first UNFCC Gender Action Plan, finalized in November of 2017, that integrates gender into all aspects of climate policy. Areas identified as critical blocks in response to climate change are; mitigation, adaptation, technological transfer, financing, monitoring and reporting. Mitigation and adaptation should effectively address gender specific impacts of climate change in the areas of food security, agriculture and fisheries, water, biodiversity, health, human rights, peace and security. Secondly technological development related to climate change should take into account women's specific priorities, needs and roles and make use of their knowledge and expertise. Women's involvement in the development of new technologies can ensure that they are user friendly, affordable, effective and sustainable. Financing must be 
flexible enough to reflect women's priorities and needs. Active participation of women in development of funding criteria and allocation of resources for climate change initiatives is critical while gender analysis of all budget lines and financial instruments is needed. The recent integration of gender considerations into key multilateral climate finance mechanisms ${ }^{55}$ are steps in the right direction. Countries must make use of the climate finance tools/resources ${ }^{56}$ available for ensuring gender responsive implementation of climate change projects and they must encourage a paradigm shift in climate finance thinking to ensure gender equality and women's empowerment dimensions are mainstreamed within all climate finance governance structures. The last pillar, monitoring and reporting requires countries to track the implementation of climate change policies. This is a good opportunity to track the effectiveness of gender mainstreaming initiatives and gender impacts of climate policies at all levels. Gender considerations and women's issues, needs and contributions should be integrated across the planning and execution cycle of climate change policies and projects. Monitoring should also focus on ensuring that, climate change and other goals in SDGs must work toward a common purpose. For example, at present individual goals on energy access and tackling climate change could contradict each other-massive expansion of fossil fuel for example, would satisfy one goal and undermine the other. These potential conflicts can be mediated by strong integrative targets. ${ }^{57}$

\section{Ensuring Full and Equal Participation of Women in Decision Making}

A comprehensive approach is needed to increase women's participation in power and decision making. Such an approach would encompass temporary special measures to achieve gender balance in decision making bodies and capacity building and training initiatives to support women's political participation at local and national levels. This calls for use of gender quotas as transitional mechanisms within electoral systems that are non-conducive to equal participation ${ }^{58}$ as well as constitutional and legal reform. In addition, governments will need to address institutional contexts of decision making to create more women friendly institutions and organizational

\footnotetext{
${ }^{55}$ Green Climate Fund (GCF) and Clean Investment Funds (CIF).

${ }^{56}$ UNDP Gender Responsive National Communication Toolkit, the Guide to Gender Mainstreaming in UNDP Supported GEF Finance Projects, the Capacity Building Package on Gender Mainstreaming in Mitigation and Technology Development and Transfer Interventions and the IUCN Climate Change Gender Action Plans (ccGAPs) (UNDP 2017).

${ }^{57}$ For example, decrease carbon intensity by increasing the share of renewable energy to $30 \%$ and increase energy intensity by $2.4 \%$ per year or scaling down biomass facilities to match the size of forest residues.

${ }^{58}$ Quotas address institutional barriers and demand action from institutional actors and power holders.
} 
structures. In industrialized countries this has been accomplished through offering subsidized or work-based childcare, maternity and paternity leave, emergency leave for care givers and introducing flexi time. In tandem addressing masculine stereotypes of power, discriminatory party practices and threats of violence against women in electoral context is an important step. This will require engaging boys and men in supporting girls and women leaders as well as holding individuals who obstruct women's abilities accountable. An increased role for women in decision making also banks on use of appropriate indicators to measure women's participation, with a focus on bringing the importance of women's local level participation to the fore. Measuring progress qualitatively and quantitatively captures the complex and changing realities of women's lives.

\section{Conclusion}

Governments exude confidence about the impending positive impact of Agenda 2030 in relation to gender equality and women's empowerment, nevertheless the textual analysis in this paper points the picture that the SDGs may fail to be as transformative as envisaged despite some clear positives. The influence of SDGs may be most significant in their ability to change the idea of development from a purely economic approach to one that includes a host of issues. The SDGs constitute an improvement with regard to gender equality and women's empowerment however, there is no room for complacency as we move to the implementation stage. Given that gender equality is a cross cutting development issue unless it is addressed in a multidimensional way it will not become a reality and not one of the SDGs will be achieved without including women and girls as equal partners.

\section{References}

Abbott KW, Keohane RO, Moravick A, Slaughter AM, Snidal D (2000) The concept of legalization. Int Organ 54:17-35

Antonopoulous R (2014) Gender perspectives and the gender impact of the global economic crisis. Routledge, New York

Buvinic M, Nichols R, Koolwal G (2014) Mapping gender data maps. Data 2x report, United Nations Foundation, Washington DC, http://www.fsnnetwork.org/sites/default/files/Data2X_ MappingGenderDataGaps_FullReport_0.pdf. Accessed 22 Nov 2017

Chopra D (2015) Balancing paid work and unpaid care work to achieve women's economic empowerment, IDS policy brief 83 . IDS, Brighton

Desai M (2010) Hope in hard times: women's empowerment and human development. Human Development Research Paper 14. United Nations Development Program, Human Development Office New York

European Parliament. Challenges and achievements in the implementation of the millenium development goals for women and girls from a European union perspective. Brussels 
Committee on Women's Rights and Gender Equality. http://www.europarl.europa.eu/RegData/ etudes/etudes/join/2014/493049/IPOL-FEMM_ET(2014)493049_EN.pdf. Accessed 14 Nov 2017

Farha F, Zhaohua L, Mohammad I (2017) Trade liberalization and gender inequality in emerging economies - from the perspective of sustainable development goals. Asian Econ Financ Rev 7 (11):1075-1092

Floro M, Willoughby J (2016) Feminist economics and the analysis of the global economy: the challenge that awaits us. Fletcher Forum World Aff 40(2):15-27

Goetz A, Jenkins R (2016a) Feminist activism and the politics of reform: when and why do states respond to demands for gender-equality policies? UNRISD working paper, no. 2016-13. United Nations Research Institute for Social Development (UNRISD), Geneva

Goetz A, Jenkins R (2016b) Gender security and governance: the case of sustainable development goal 16. Gend Dev 24(1):127-137

Gideon J, Porter F (2014) Unpacking women's health in public private partnerships: a return to instrumentalism in development policy and practice. Wider Working Paper No. 2 2014/009 Helsinki United Nations University (UNU Wider). https://www.wider.unu.edu/sites/default/ files/wp2014-009.pdf. Accessed 29 Oct 2017

Goldstein J, Kahler M, Keohane R, Slaughter A (2000) Introduction: legalization and world politics. Int Organ 54(3):385-399

Half A, Sovacool B, Rozhon J (2014) Energy poverty: global challenges and local solutions. Oxford University Press

Hazelton A (2015) Africa: Science and Post 2015 SciDev.Net. http://allafrica.com/stories/ 201502190939.html. Accessed 27 Dec 2017

Heillenbrand E, Karim N, Mohanraj P, Wu D (2015) Measuring gender-transformative change: a review of literature and promising practices. CARE USA for World FISH and the CGIAR Research Program on Aquatic Agricultural Systems

Hickel J (2015) The problem with saving the world. Jacobian, New York. https://www.jacobinmag. com/2015/08/global-poverty-climate-change-sdgs/. Accessed 15 Nov 2017

Htun M, Weldon L (2012) The civic origins of progressive policy change combating violence against women in global perspective, 1975-2005. Am Polit Sci Rev 106(3):548-569. http:// journals.cambridge.org/abstract_S0003055412000226. Accessed 27 Nov 2017

Kaltenborn M, Kuhn J (2017) SDGs acceptance not enforcement. D+C e paper

Karlsson-Vinkhuyzen S, Vihma A (2009) Comparing the legitimacy and effectiveness of global hard and soft law: an analytical framework. Regul Gov 3(4):400-420

Koehler G (2016) Tapping the sustainable development goals for progressive gender equity and equality policy. Gender Dev 24(1):53-68

Marone H (2016) Demographic dividend gender equality and economic growth: the case of Cabo Verde. IMF Working Paper WP/16/169

Mazur A, Hoard S, McBride D (2012) Women's movement change: conceptualization, measurement and investigation. APSA 2012 annual meeting paper. Available at SSRN. https://ssrn.com/ abstract $=2107885$

McArthur J (2013) Own the goals: what the millennium development goals have accomplished. Foreign Aff 92:152-162. https://www.foreignaffairs.com/articles/2013-03-01/own-goals. Accessed 14 Nov 2017

Merry S (2016) Cultural dimensions of power/knowledge: the challenges of violence against women. Sociologie du Travail 58(4):370-380

Nayana B, Das N (2017) Women's inheritance rights, household allocation and gender bias. Am Econ Rev 107(5):150-153

Nayyar D (2012) The MDGs after 2015: some reflections on the possibilities. Paper prepared for the UN System Task Team on the Post 2015 UN Development Agenda

O'Dell K, Peters S, Wharton K (2014) Women, energy and economic empowerment. Deloitte University Press 
Onaran O (2015) The role of gender equality in an equality led sustainable development strategy. Greenwich Political Economy Research Center. No: GDERC26

Patchell J, Hayter R (2013) Environmental and evolutionary economic geography: time for EEG2? Geografiska Annale: series B. Hum Geogr 95(2):111-130

Pogge T, Sengupta M (2015) The sustainable development goals (SDGs) as drafted: nice idea, poor execution. Wash Int Law J 24(3):571

Ponte N, Enriquez A (2016) Agenda 2030: a bold enough framework towards sustainable, genderjust development? Gender Dev 24(1):83-98. https://doi.org/10.1080/13552074.2016.1142227. Accessed 10 Nov 2017

Razavi S (1997) Fitting gender into development institutions. World Dev 25(7):1111-1126

Razavi S (2016) The 2030 agenda: challenges of implementation to attain gender equality and women's rights. Gend Dev 24(1):25-41

Romero M (2015) What lies beneath? A critical assessment of PPPs and their impact on sustainable development. Eurodad, Brussels. http://www.eurodad.org/files/pdf/1546450-what-liesbeneatha-critical-assessment-of-ppps-and-their-impact-on-sustainable-development-1450105297.pdf. Accessed 22 Nov 2017

Rottach E, Schuler R, Hardee K (2009) Gender perspectives improve reproductive health outcomes: new evidence. Population Reference Bureau, Washington, DC

Sharma S, Beaton C, Merill L, Kitson L, Phillip G (2016) Gender and fossil fuel subsidy reform: implications for India, Bangladesh and Nigeria. In: Green Growth Knowledge Platform (GGKP) Fourth Annual Conference on Transforming Development Through Inclusive Green Growth 6-7 September 2016 Jeju International Convention Center, Republic of Korea

Shelton D (1997) Compliance with international human rights soft law. Stud Transnatl Legal Policy 29:119

Sinha A, McRoy R, Berkman B, Sutherland M (2017) Drivers of change: examining the effects of gender equality on child nutrition. Child Youth Serv Rev 76:203-212

UN (2015) Res 69/313, Addis Ababa Action Agenda for the third international development conference on financing and development. UN Doc A/RES/69/313.2015c

UN Women (2013) A transformative stand alone goal on achieving gender equality, women's rights and women's empowerment: imperatives and key components. UN Women, New York. http:// wps.unwomen.org/ /media/files/un\%20women/wps/highlights/unw-global-study-1325-2015. pdf. Accessed 15 Nov 2017

UNDP (2017) Gender and Climate Finance Policy Brief 5-WEB

Van Beers C (2000) Labor standards and trade flows of OECD countries. World Econ 21(1):57-73

Wolf J (2011) Climate change adaptation as a social process. In: Ford JD, Berrang Ford L (eds) Climate change adaptation in developed nations: from theory to practice. Springer, Dordrecht. https://link.springer.com/chapter/10.1007/978-94-007-0567-8_2. Accessed 23 Dec 2017

Josephine A. Odera is the Director of ACTIL (Africa Centre for Transformative \& Inclusive Leadership). Before her appointment at ACTIL, she was the Regional Director, West and Central Africa, UN Women and then briefly served as Regional Advisor, Leadership \& Governance at the United Nations Women Regional Office for East and Southern Africa. Mrs. Odera holds a Doctor of Philosophy $(\mathrm{PhD})$ degree in Conflict Management from the University of Ghent, Belgium having previously obtained a master's degree in Economics, a Bachelor of philosophy degree in Economics and a Bachelor of Arts degree.

She has served in the Ministry of Foreign Affairs and International Cooperation of the Republic of Kenya and also taught at the University of Nairobi, Kenya, worked in Civil Society as a Director of Programmes and most recently as Regional Director in the United Nations. As a government official, Dr. Odera represented the Government of Kenya in various meetings including the UN General Assembly, ECOSOC, African Union, regional trade and cooperation meetings such as 
COMESA. Dr. Odera was also a pioneer for the review of Foreign Service regulations as they affected women. She has also served as joint secretary to various bilateral commissions of the Republic of Kenya. She has served as a Senior Program consultant for UNDP in Addis Ababa and has undertaken numerous other consultancies in the Horn of Africa and the Great Lakes region.

Judy Mulusa is a Professor of Economics at Prince George's Community College (USA) and an adjunct professor at Bowie State University (USA). She also serves as a Research Associate for Claret Consulting a consulting firm involved in public private partnerships and infrastructure projects. Although her research interests are broad she has a particular interest in economic growth and development, economics or urban redevelopment and public finance. She has most recently published work on gentrification and the housing market in the United States. Previously Judy held faculty positions in her native country, Kenya at Moi University and at Masinde Muliro University of Science and Technology. She also served as an Economist with the Ministry of Finance. Judy received a B. A. in economics and political science minor from the University of Nairobi in Kenya, an M. A. in Economics from the University of Botswana and a Ph. D. in Economics from Howard University (USA).

Open Access This chapter is licensed under the terms of the Creative Commons Attribution 4.0 International License (http://creativecommons.org/licenses/by/4.0/), which permits use, sharing, adaptation, distribution and reproduction in any medium or format, as long as you give appropriate credit to the original author(s) and the source, provide a link to the Creative Commons licence and indicate if changes were made.

The images or other third party material in this chapter are included in the chapter's Creative Commons licence, unless indicated otherwise in a credit line to the material. If material is not included in the chapter's Creative Commons licence and your intended use is not permitted by statutory regulation or exceeds the permitted use, you will need to obtain permission directly from the copyright holder.

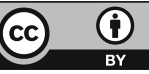

